\title{
Model of Fulfilling the Rights of Displaced Children with Special Needs with Mental Disabilities in North Aceh
}

\author{
Eny Dameria* Nuribadah \\ Law Faculty, University of Malikussaleh Indonesia \\ * E-mail of the corresponding author: enydameria@unimal.ac.id
}

\begin{abstract}
Model of Fulfillment of The Rights of Abandoned Children with Special Needs with Mental Disabilities in North Aceh, Because Children as the nation's buds are expected to be the next generation that has the potential to build a state so that it must be protected from all forms of inhumane treatment in order to be able to be responsible for the sustainability of the nation and state. However, if an abandoned child has a mental disability it is feared that the creation of a generation that is not intellectually and sensorily qualified due to lack of education and poor mental health, the protection and rights of children with mental disabilities are regulated in Law No. 23 of 2002 on Child Protection. This research aims to know and analyze and to see the duties and functions of the government in fulfilling the rights of displaced children with special needs with mental disabilities by the Government of North Aceh Regency, and to identify the model of fulfilling the rights of children with special needs with mental disabilities in North Aceh.
\end{abstract}

Keywords: Model of Protection, Child With Disabilities, North Aceh

DOI: $10.7176 / \mathrm{JLPG} / 118-12$

Publication date: February $28^{\text {th }} 2022$

\section{A. Introduction}

This research is motivated by the state of children as the next generation that has the potential to build a country. Children must be protected by all parties, whether by the family, environment, or the state as the ruler, from all forms of unfair and inhumane treatment to be able to be responsible for the sustainability of the nation and state.

The Constitution of the Republic of Indonesia 1945 in Article 34 paragraph (1) states that "Poor and Abandoned Children are maintained by the State" from the sound of the article hints that the child is the subject of the law of national law that must be protected, maintained and fostered to achieve his welfare. In other words, children are the responsibility of the government and society together.

The number of displaced children in the North Aceh Regency is around 3,778 people with the number of children with disabilities around 950 people. The head of the Social Rehabilitation Section of the Social Rehabilitation and Mobility Department of North Aceh Regency said most of the displaced children were in the Lhoksukon, Geulinggang uteun area, and Baktiya Barat North Aceh. This situation is influenced by environmental factors, lack of parental care resulting from the lack of knowledge about handling children with special needs. Shame and the notion that children with special needs are considered a disgrace to some families and communities is also one of the factors in the neglect of children with mental disabilities with special needs. Child protection is an effort to realize justice in a society so that every child can carry out their rights and obligations, thus child protection must be pursued in various areas of the state and community life. (Arif Gosita, 1989).

Research model of the fulfillment of the rights of children with special needs with mental disabilities needs to be done because the treatment for children with mental disabilities is different from general disabilities, the extent to which there are schools and homes available for children with mental disabilities, because so far the existing treatment is for general disabilities, both physical disabilities, intellectual disabilities, and sensory disabilities.

Several previous studies have relevance to the topic of the model of fulfilling the rights of children with special needs with mental disabilities in North Aceh: Solvia Indah (2019) with the title: Legal Protection of Children with Special Needs Who Are Victims of Sexual Violence (A Study In the Jurisdiction of the District Court of Singkil Aceh). The results showed that the legal protection of children with special needs who are victims of sexual violence crimes begins with a closed and separate examination, conducted by a professional person to connect with victims who have physical limitations. The Integrated Service Center for Women and Children Empowerment (P2TP2A) has been very helpful in restoring victims so as not to feel alienated and depressed about the events experienced. In solving cases there is a shortage of professionals to communicate with children with special needs, a lack of budget from the government, and a lack of psychologists or psychics in P2TP2A.

The difference between this study and the research being conducted by researchers is that researchers research the model of fulfilling the rights of children with special needs with disabilities means that the author examines the rights of children with mental disabilities specifically in the North Aceh region, while previous 
research was more specifically about the protection of children with special needs victims of sexual violence.

Neno Safitri, (2018), Legal protection of the right to education of children with disabilities in Surabaya city: fulfillment of educational rights for children who include children with disabilities. Lack of supervision and implementation of the protection of children with disabilities by local governments so that children with disabilities do not have the same rights in pursuing educational rights including formal and non-formal education. The number of children with disabilities in Surabaya city who do not pursue education like children in general. Lack of provision and facilities of schools for children with disabilities so that the right to education of children with disabilities and protection of educational rights for children with disabilities are not fulfilled.

\section{Review of Abandoned Children}

According to the Ministry of Social Affairs, street children are children who spend some of their time making a living or roaming the streets or other public places. (Imam Sukadi, (2013). The situation of the environment is bad and far from prosperous becomes a place that is very vulnerable to crime. This is not good for the growth of children, with the background of families who cannot afford, high poverty rates, the family loss will increase the number of homeless children. Social places such as orphanages also cannot completely accommodate children who are on the streets as a whole.

The factors that cause a child to become displaced are the loss of parents, factors of family social status, factors of family disorganization, internal household conflicts, economic conditions that concern even conflicts between children and parents. It is at the age of children that one needs affection and attention in shaping the character of a person. The Constitution of the Republic of Indonesia of 1945 Article 34 paragraph (1) states that "Poor families and abandoned children are cared for by the state". Therefore the state is obliged to care for abandoned children in this case assisted by DSP3.

\section{Child Mental Disability Rights Fulfillment Model}

Mental disability is also known as mental disorder. Children are very influential and comparable to their physical health, if a child has mental problems it will be bad for growth. Mental disorders in children are not more than the number of people with mental disorders in adults, but if mental disorders experienced by children are not handled further it is feared that it can affect mindset, emotional level, behavior, even depression, to refer to mental disorders. (Melvin Lewis, 1996, 502).

\section{B. RESEARCH METHOD}

This research is qualitative research, the approach in this research is empirical legal research / sociological legal research to obtain data based on information from the Social Service and informants as a source of data through research activities with interviews, whether structured or not. The data collection techniques used in this study are of three types, namely observation, interview, and documentation (Herdiansyah, 2011). The observations referred to in this study are non-participant observations. While interviews with informants are conducted indepth, in an unstructured way. The documentation data in this study is books, journals, articles, and websites related to this research (Khotijah, 2018).

The results of data collection and information in this study through a literature study of the initial assumptions or hypotheses used in answering the problem. Then tested in a verifiive inductive inductive manner on the facts contained in the Model group for the fulfillment of the Rights of children with special needs with disabilities in North Aceh. The reality / circumstances of children with special needs with disabilities in the community is the primary data that will be categorized in a model of protection of children with special needs in North Aceh. Data that has been collected and has gone through the verification stage will be carried out to check the validity. Data analysis is an activity in research in the form of studies or studies on the results of data management that is assisted by existing theories. The results of the analysis will produce a model for the implementation of child protection with special disabilities in North Aceh.

\section{RESULTS AND DISCUSSIONS}

The implementation of the study was carried out by a team of researchers by directly collecting data in the North Aceh Regency area with several related agencies, namely the Social Service empowerment of women and children, the Central Statistics Agency, and also mental disability schools with special needs. The results of the field study provides an overview of how the model of protection of children with special needs with disabilities in North Aceh.

Data on the number of people with mental disabilities (idiots) is still very minimal in the North Aceh regency, while the fact on the ground there are several families who have children with disabilities idiots who are not recorded. The number of displaced children in the North Aceh Regency is around 3,778 people with the number of children with disabilities around 950 people. Most of the abandoned children are found in lhoksukon, West Baktiya and Uteuen Geulinggang and surrounding areas. It is also influenced by environmental factors, 
very minimal family knowledge about how handlers with mental disabilities, shame and shame, to the care of parents who are minimal for the condition of their children. In addition, the most basic thing about the lack of support for people with mental disabilities is the absence of a home that specifically handles children with special needs.

The legal umbrella for children with disabilities is the Constitution of the Republic of Indonesia of 1945 Article 34 paragraph (1) states that "Poor and abandoned children are maintained by the state" the article is an embodiment of efforts to protect the rights of children. According to Law No. 23 of 2002 on Child Protection, Article 1 paragraph (2) "Child protection is all activities to guarantee and protect the child and his rights to live, grow, develop, and participate, optimally by the dignity and dignity of humanity, and get protection from violence and discrimination.

Based on the Law of the Republic of Indonesia Number 11 of 2006 concerning the Government of Aceh the administration of government affairs as referred to in Article 12 paragraph (2) which reads: "The implementation of government affairs as referred to in paragraph (1) is regulated and taken care of by the Government of Aceh and the district/city government. Qanun Aceh Number 11 of 2008 concerning Child Protection, Article 34 Paragraph (1), (2), And (3):

1. Every child is entitled to protection in disaster emergencies, armed conflicts, and social conflicts.

2. The Government of Aceh and the district/city government are obliged and responsible for the protection as referred to in paragraph (1).

3. Obligations and responsibilities as referred to in paragraph (2) include the prevention of everything that befalls and can harm the child in emergency situations and the provision of services needed by the child to be able to live his life normally physically, mentally, and socially.

DSP3A in performing services to the people of North Aceh Regency in collaboration with the District Social Workforce (TKSK) and local village officials. TKSK itself is someone who is given duties, functions, and authority by the government through the Ministry of Social Affairs in accordance with The Minister of Social Affairs Regulation number 28 of 2018 on Subdistrict Social Welfare Personnel. TKSK is domiciled in the subdistrict and usually numbers 1 person. TKSK itself works in sub-districts that include villages or villages. This is very helpful for the DSP3A in conducting direct research in accordance with what has been reported by the community. When the visit is seen how the condition of the child why he can be displaced, the companion will ask the relatives of the child and the surrounding community about the condition of the child in his daily life. (Al Muttaqin : 2021).

Information and data on children with disabilities with special needs in North Aceh Regency are not received has not been recorded in the Office of Social Service for Women Empowerment and Child Protection, because every receipt of reports by local residents of the child is directly taken to a public orphanage that is willing to accept, not a special home for mental disabilities. So there is no definitive data on the classification of persons with disabilities and the amount of data on abandoned children in North Aceh Regency.

The model of fulfilling the rights of displaced children with special needs with mental disabilities is ideal to be applied by the Government of North Aceh Regency. Indonesia ensures the survival of every citizen, including persons with disabilities who have the same legal standing and human rights as Indonesian Citizens and as an integral part of Indonesian citizens and society is the trust and gift of God Almighty, to live forward and develop in a fair and dignified manner. Furthermore, most people with disabilities in Indonesia live in vulnerable, underdeveloped, and/or poor conditions due to still restrictions, obstacles, difficulties, and reduction or removal of the rights of persons with disabilities. Implementation and Fulfillment of rights, Persons with Disabilities based on:

a. Respect for dignity;

b. individual autonomy;

c. without discrimination;

d. full participation;

e. diversity of human beings and humanity;

f. Equality of Opportunity;

g. equality;

h. Accessibility;

i. the ever-evolving capacity and identity of the child;

j. inclusive; and

k. special treatment and more protection.

The Ministry of Social Affairs supported by Bappenas will also launch two government regulations, namely Government Regulation No. 52 of 2019 on the Implementation of Social Welfare for Persons with Disabilities and Government Regulation Number 70 of 2019 on Planning, Organizing, and Evaluating respect, protection, and fulfillment of the rights of persons with disabilities. Government Regulation Number 52 of 2019 affirms the four pillars of social welfare implementation, namely Social Rehabilitation, Social Empowerment, Social 
Protection, and Social Security.

Government Regulation No. 70 of 2019 provides guidelines in the planning, implementation and evaluation of the fulfillment of the rights of persons with disabilities outlined in the Master Plan of Persons with Disabilities (RIPD). RIPD contains vision, mission, strategic goals, policies, implementation strategies, and achievement targets and has seven strategic goals, namely inclusive data collection and planning; Provision of an environment without obstacles; Protection of political rights and access to justice; Empowerment and inclusive economic independence; Education and skills; access and equitable distribution of health services.

RIPD is a reference in the preparation of the National Action Plan of Persons with Disabilities (RAN PD) and the Regional Action Plan of Persons with Disabilities (RAD PD) province. Thus the efforts made will cover the central to regional levels, so that Indonesia's Inclusion, Superior Disability can be realized.

From the results of the study that there are already several schools for children with disabilities, including: Yayasan Pendidikan Anak Cacat (SLB YPAC) Dewantara in Uteun Geulinggang, Dewantara Kruengeukuh District, Extraordinary School (SLB) Of Bina Bangsa District Syamtalira Aron, and School Of Disabled Children Education Foundation Aneuk Nanggroe Sawang (YPAC Aneuk Nanggroe), from the results of research the schools do not deal with children with mental disabilities specifically, Unless it addresses disability in general. Public disability dormitories were once provided by the school, but since the covid 19 pandemic, the dormitory was eliminated by the agency. (Nadia Laila, S.Pd.: 2021).

The treatment of displaced children with special needs with mental disabilities should be handled by mental and mental health specialists, so far patients who come to consult and do the treatment of only children who have families, families who are quick to respond to bring children with mental disabilities to be treated. But he also added that until now there has been no cooperation bond carried out by the DSP3A Office with the Cut Mutia General Hospital. (Mila Astari Harahap, North Aceh RSCM mental specialist, interview 17-10 2021).

The report received by the Central Bureau of Statistics of North Aceh Regency regarding data on people with Mental Disabilities has been input by the report provided by the Social Service for Women Empowerment and Child Protection and the financial assistance obtained in accordance with the available report.

Supposedly, in the opinion of researchers to facilitate the fulfillment of the rights of children with disabilities handled by the Regency/City is allowed to Form a Committee on the Protection and Fulfillment of Persons with Disabilities, both the regulation of the Regulation as the legal umbrella and the Decree of the Committee team including its budgeting. So that in regulation, HR, managerial and system handled properly. The task of the Committee for the Protection and Fulfillment of Persons with Disabilities is to record how many people with disabilities are in the City by name by address and update regularly related to existing data. But it doesn't exist or forms yet.

In addition to being able to do data collection, they must also receive pokja teams and technical teams also receive complaints and follow up on existing complaints, then provide recommendations to the competent officials in order to be resolved over the problems received. With the Committee able to map the data of persons with disabilities according to the existing type, thus facilitating classification for its resolution, this Committee can also issue an assessment of the performance of local governments in the implementation of respect, protection and fulfillment of the rights of persons with disabilities, even when there are people with disabilities dealing with legal problems, then this team can mediate to help resolve them.

The expectation from the extraordinary school said that the desired model was: having a teacher handle children the ideal would be: 1 student 1 teacher, because so far 1 teacher 15 students handling children with different disabilities Availability of more adequate facilities and infrastructure, and the curriculum is more effective, (Hirwan Syahputra, S.Pd: 03:10:2021).

The Model of Fulfillment of the Rights of children with special needs in North Aceh regency, has been by the laws and regulations, the District Government and the community organize Social Welfare efforts for displaced children under five, abandoned children, children who face the law, street children, children with disabilities, children who are victims of violence, and children who need special protection. The duties and functions of the Government of North Aceh Regency in fulfilling the rights of displaced children with special needs with mental disabilities, its obligations as an agency are charged with the task of protecting and maintaining displaced children ranging from empowerment, assistance, social security, services, social rehabilitation, to child protection. So, dealing with the subject of abandoned children who have mental disabilities is the responsibility of DSP3A.

\section{CONCLUSION}

The Model of Fulfillment of the Rights of children with special needs in North Aceh regency, has been by the laws and regulations, the District Government and the community organize Social Welfare efforts for displaced children under five, abandoned children, children who face the law, street children, children with disabilities, children who are victims of violence, and children who need special protection. The duties and functions of the Government of North Aceh Regency in fulfilling the rights of displaced children with special needs with mental 
disabilities, its obligations as an agency are charged with the task of protecting and maintaining displaced children ranging from empowerment, assistance, social security, services, social rehabilitation, to child protection. So, dealing with the subject of abandoned children who have mental disabilities is the responsibility of DSP3A. The ideal model of fulfilling the rights of displaced children with special needs with mental disabilities to be applied by the Government of North Aceh Regency, is to provide assistance with direct dissability aids such as wheelchairs, hearing devices; Trauma healing for people with mental disabilities including people with mental disorders (ODGJ) performed by psychologists from social services descends directly on home and school. There are several things that become field studies, among others: SLB Bina Bangsa Desa Pante, Teupin Punti Syamtalira Aron District, SLB Babul Huda Jungka Gajah, and SLB Blang Jrum in Blang Jrum. These schools do not deal with children with mental disabilities specifically, but rather deal with disabilities in general. Public disability dormitories were once provided by the school, but since the covid 19 pandemic, the dormitory was eliminated by the agency. Until now, homes and schools specifically for children with mental disabilities do not yet exist in North Aceh. It is important that the condition of children with mental disabilities who have not been fulfilled rights get protection from violence, discrimination, exploitation, stigmatization, labeling.

\section{BIBLIOGRAPHY}

Afrilia Ardianto, 2013, Praktik Sosial Anak Kebutuhan Khusus yang Mengikuti Behaviour Theraphy, Paradigma. American Psychiatric Association, 1994, Diagnostic and statistical manual of mental disorder, Fourth Edision, Washington DC.

Arif Gosita, , 1989, Masalah Perlindungan Anak, Akademika Presindo, Jakarta. BambangWaluyo, 2002, PenelitianHukumDalamPraktek, SinarGrafika, Jakarta. Barnados, 2015, Young Children Grieve Too, Orchard View Ring Mahon Road

Buku Panduan Akademik Fakultas Hukum Universitas Malikussaleh, 2015, hlm.112.Unimal Press, Lhokseumawe.

Cairins, Neckerman, 1999, Stormshak \& Webster.

Carole Wade, Carol Travis, 2008, Psikologi, edisi 9 jilid 1, Jakarta : Erlangga.

Chaplin, C.P., 1989,kamus Lengkap Psikologi, Terj. Kartini Kartono, Jakarta: Rajawali Press,.

Cholid Narbuko, 7 Abu Achmadi, 2009, Metode Penelitian, cet. X, hlm.1. Jakarta: PT.Bumi Aksara.

Departemen Sosial RI.2001. Interverensi Psikososial, Hal. 20

Irlandia. 